\title{
RZECZYWISTOŚĆ ESCHATOLOGICZNA W LIŚCIE DO HEBRAJCZYKóW *
}

W świadomości przeciętnego chrześcijanina czas i wieczność pojmowana bardziej na sposób filozoficzny niż biblijny stoją na antypodach do tego stopnia, że o wieczności mówi się przez negację czasu.

W Theologisches Wörterbuch zum NT, pod hasłem aiōn autor uzasadniając niemożliwość pogodzenia panțeistyczno-astrologicznej nauki Wschodu o wiecznych powrotach $\mathrm{z}$ biblijną koncepcją jednorazowego biegu świata pisze: „Połączenie dualistycznej nauki o czasie wieczności $\mathrm{z}$ terminologią nauki o powrocie jest wewnętrznie sprzecznym poglądem na obydwa ,eony”, na ten obecny i przyszły. Obecny ,eon” utożsamia się $\mathrm{z}$ erą świata, którego (syntéleia) koniec nadszedł. Przyszły „eon”, „przyszła era świata” to jest to nowe, które dopiero nastąpi. Jest to coś, czego nie można sobie wyobrazić, co sobie tylko można uzmysłowić za pomocą porównania: za pomocą obrazu ,,państwa Bożego", wziętego z historii, z przestrzennym obrazem ,,jako nowe niebo, oraz nowa ziemia”, w kategorii czasu jako „nowa era”. Wewnętrzna sprzeczność polega na tym, że usiłuje się myśleć w kategorii czasu o czymś, co właściwie stoi w sprzeczności z czasem. Ponieważ obecny „eon" stoi w takim stosunku do przyszłego, jak czas do wieczności". ${ }^{1}$

O ile takie ujęcie czasu i wieczności jest uprawnione z punktu widzenia filozofii, o tyle na gruncie biblijnym kontrast ten musi zostać znacznie stonowany, bo powiązania między tymi rzeczywistościami są o wiele głębsze. Nie chodzi tu tylko o fakt prostego następstwa. Pierwiastek bowiem niebieski obecny jest w doczesności, kształtuje ją i wewnętrznie przeobraża. Bardzo trafnie i precyzyjnie wyraził tę współ-

* Artykuł niniejszy jest przeredagowanym tekstem pracy licencjackiej napisanej na Papieskim Wydzilale teologicznym w Krakowie pod kierunkiem O. A. Jankowskiego. OSB.

1 ThW I, 205. 
zależność J. Bonsirven: „to, co wieczne zakorzenia się w czasie, a czas utrwala się w wieczności". ${ }^{2}$

Jasną jest rzeczą, że nie biblijne i przesadne rozłączanie i przeciwstawianie czasu i wieczności nie wpłynęło dodatnio na właściwe naświetlenie zagadnień eschatologicznych. O eschatologii, którą najczęściej sprowadzało się do tak zwanych czterech rzeczy ostatecznych, myśli się, zgodnie zresztą $\mathrm{z}$ samą nazwą, jako o czymś, co będzie wprawdzie aktualne, ale kiedyś przy końcu świata, w czasach ostatecznych, czy też biorąc rzecz w skali indywidualnej po śmierci poszczególnego człowieka. Jeśli mówi się o jakiejś jedności i współzależności między czasem, a wiecznością, między tym, co jest teraz, a co dopiero nastąpi, to czyni się to przeważnie na płaszczyźnie teologii moralnej. Zasługa względnie wina, która możliwa jest tylko w doczesności, a od której zależy ostateczna przyszłość człowieka, stanowi w świadomości wiernych prawie jedyne ogniwo łączące te dwie rzeczywistości. Popularnie wyraża się to $\mathrm{w}$ nauczaniu $\mathrm{w}$ następującym postulacie: podejmuj wysiłki związane $\mathrm{z}$ chrześcijańskim życiem, unikaj zła, czyń dobro, dąż do doskonałości ukazanej nam przez Chrystusa, a kiedyś po śmierci otrzymasz za to nagrodę. Prawdą jest, że w tym właśnie punkcie katolickiej nauki logos musi wywierać szczególnie mocny wpływ na ethos, ale też, jeśli ma tak rzeczywiście być, to nauka ta stanowiąca fundament i drogowskaz dla postępowania moralnego musi zostać wydobyta i ukazana $w$ jak najpełniejszym świetle. Tak, jak ją widzieli i żyli nią członkowie pierwotnego Kościoła. Każdego, kto weźmie do ręki Pismo św., uderza ogromnie eschatologiczna orientacja pierwszych gmin chrześcijańskich. Do tego stopnia, że niektóre teksty Pisma św. dotyczące tego właśnie zagadnienia sprawiły mnóstwo kłopotów egzegetom. Można by przypuszczać, że przyczyną wielu trudności było i jest nie dość biblijne podejście do biblijnych tekstów. $\mathrm{Z}$ biegiem czasu odeszło się $\mathrm{w}$ pojmowaniu tych zagadnień zbyt daleko od nastawienia pierwotnego, dlatego też wzrósł stopień trudności $\mathrm{w}$ zrozumieniu pewnych sformułowań, do których podchodzi się z kategoriami późniejszej myśli teologicznej.

Zadaniem niniejszego artykułu jest zwrócenie uwagi, że współzależności między czasem, a wiecznością, między życiem obecnym i przyszlłym nie sposób zawężać tylko do dziedziny moralnej, gdyż istnieją między nimi aktualne powiązania natury ontologicznej, które są owocem zbawczego dzieła Chrystusa. Zakres tego artykułu jest bardzo ograniczony, chodzi bowiem tylko o zarys myśli eschatologicznej zawartej w jednej tylko księdze Pisma św. mianowicie w Liście do Hebrajczy- 
ków. Trzeba wszakże pamiętać, że mamy do czynienia z dokumentem późniejszym w stosunku do większości Ksiąg Pisma św., w którym wyraźnie widać już ślady poważnie zaawansowanej syntetycznej i systematycznej pracy teologa. Warto przy tym zaznaczyć, że eschatologia tego listu pokrywa się prawie zupełnie $\mathrm{z}$ koncepcją eschatologiczną zawartą w listach ściśle Pawłowych.

Odnośnie samych tekstów, które mówią wprost o zrealizowanym już eonie przyszłym, warto podkreślić, że jest ich stosunkowo niewiele. Mała ich ilość jest jednak rekompensowana przez kontekst, czyli że wyrażając się jaśniej, przez ważną rolę jaką w Liście spełniają. Występują bowiem tam, gdzie autor, zgodnie $\mathrm{z}$ założeniem całego Listu wykazuje wyższość Nowego Przymierza nad Starym. Zwrócenie uwagi adresatom, że zawarte przez Chrystusa Nowe Przymierze otwiera ludziom dostęp do upragnionych przez Stary Testament „dóbr przyszłych" jest najważniejszym argumentem, jakiego używa autor, by przekonać czytelników o bezwzględnej wyższości Nowego Testamentu i konieczności jego przyjęcia. Dlatego też ma rację J. Cambier, kiedy pisze, że celem Listu do Hebrajczyków jest przypominanie Chrystusowego orędzia o „dobrach przyszłych”. Zdaniem tego autora tekst: „Nie aniołom bowiem poddał przyszły świat, o którym mówimy" $(2,5)$, mógłby stanowić dobry tytuł dla całego Listu ${ }^{3}$. Ograniczenie się tylko do wspomnianych tekstów byłoby uproszczeniem, dlatego trzeba było uwzględnić przynajmniej częściowo także te miejsca, które mówią o zadaniach stojących $\mathrm{w}$ perspektywie przyszłości przed chrześcijanami uczestniczącymi już w świecie niebieskim i kosztującymi „dóbr przyszłych". Uwzględnienie tych dwu grup tekstów chroni przed krańcowymi i błędnymi poglądami „eschatologizmu konsekwentnego" z jednej, a „eschatologizmu zrealizowanego" z drugiej strony. Pozwala natomiast uchwycić właściwą proporcję i stosunek między tym, co według eschatologii opartej na Piśmie św. jest już zrealizowane i stale rozwijające się, a tym, co dopiero ukaże się jako wynik ostatecznego dokonania.

DOBRA PRZYSZEE DOSTĘPNE SA DLA CHRZESCIJAN JUZ PODCZAS ŻYCIA NA ZIEMI

Istota zagadnienia leży $\mathrm{w}$ tym, że autor Listu do Hebrajczyków pisząc o rzeczach należących do struktury „świata przyszłego" przedstawia je jako już obecne $\mathrm{i}$ to istniejące na tym świecie, dostępne dla ludzi i w nich przejawiające swoją moc. Na pierwszy rzut oka w twierdzeniach autora, że przyszły świat poddał Bóg nie aniołom, lecz Chry-

3 Eschatologie ou Hellénisme dans l'Épître aux Hebreux, w: Sylloge excerptorum e dissertationibus ad gradum Doctoris..., XVIII, Lovanii 1950, 19. 
stusowi (2, 5), że Chrystus zjawił się na ziemi jako arcykapłan , dóbr przyszłych" $(9,11)$, czy też w zdaniu wyrażającym najmocniejszą w tym względzie treść, że niektórzy ludzie zakosztowali już mocy „przyszłego wieku" (6, 5), zawiera się jakaś sprzeczność. Już na podstawie tak prymitywnie dokonanego zestawu tekstów można ogólnie stwierdzić, że w jakiś sposób przyszłość, a w każdym razie pewne jej elementy zawierają się w teraźniejszości, są w niej obecne, przenikają ją.

Trzeba więc teksty te poddać najpierw analizie, by później wydobyć z nich treść teologiczną, jaką zamknął tam natchniony autor. „Niemożliwe jest bowiem tych, którzy raz zostali oświeceni, a nawet zakosztowali daru niebieskiego i stali się uczestnikami Ducha Świętego, zakosztowali również wspaniałości słowa Bożego i mocy przyszłego wieku, a [jednak] upadli, odnowić ku nawróceniu" $(6,4-5)$.

W przytoczonym wyżej zdaniu Listu do Hebrajczyków autor wymienia wielkie dary, które stają się udziałem każdego chrześcijanina, a których ewentualne odrzucenie przez apostatę stanowi główną przeszkodę $\mathrm{w}$ powtórnym nawróceniu się odstępcy ${ }^{4}$. O wielkości i randze tych Bożych darów, które są w posiadaniu chrześcijan, a zarazem okropności grzechu, polegającego na ich odrzuceniu, świadczy twierdzenie autora zawarte w następnym wierszu, że apostaci „krzyżują w sobie Syna Bożego i wystawiają Go na pośmiewisko" (6, 6). Wzgardzanie więc tymi dobrami, odrzucenie ich, jest grzechem równym grzechowi bogobójstwa, jest bowiem na płaszczyźnie indywidualnego życia (,krzyżują w sobie") wydaniem wyroku na Syna Bożego, powtórzeniem tragedii z Golgoty.

Takie ostrzeżenie skierowane przez natchnionego pisarza do chrześcijan orientuje nas od razu, o jakie wartości tu chodzi. Dobrodziejstwa te są następujące: chrześcijanie zostali oświeceni, zakosztowali daru niebieskiego, stali się uczestnikami Ducha Świętego, zakosztowali wspaniałego słowa Bożego i zakosztowali mocy przyszłego wieku.

Odnośnie pierwszego daru jest rzeczą oczywistą, że chodzi o oświecenie duchowe, wewnętrzne, o jakieś rozjaśnienie dokonywane w duszy człowieka przez Boga, zwłaszcza zaś przez Chrystusa ${ }^{5}$. Może tu również wchodzić $\mathrm{w}$ grę oświecenie intelektualne, czyli po prostu zwyczajne pouczenie wchodzące $\mathrm{w}$ zakres katechizacji Kościoła. Pouczenie

4 Zagadnienie niemożliwości powtórnego nawrócenia się przekracza ramy artykułu, stąd też ogólnie można tylko powiedzieć, że najprawdopodobniej chodzi tu o niemożność moralną, a więc względną.

5 Prawdziwym światłem, które oświeca człowieka jest Słowo, por. J. 1, 9; Ef $5,14$.

Bóg oświetla swoją jasnością Jeruzalem niebieskie, por. Ap 22, 5.

Swiatło udzielone przez Boga człowiekowi daje mu poznanie i zrozumienie prawdziwego Boga i sensu życia, por. $2 \operatorname{Tm} 1,10$. 
to jednak, jeśli ma być skuteczne, to i tak musi zostać wsparte wewnętrzną łaską Bożą.

Oświecenia udziela Bóg przez łaskę wiary, ${ }^{6}$ dlatego też wierzący nazwani są synami światłości. ${ }^{7}$ Niewierni natomiast nie mogą otrzymać oświecenia (phōtismós) Ewangelii. ${ }^{8}$

Już same terminy, których użył w omawianym zdaniu autor, a które egzegeci wiążą powszechnie $\mathrm{z}$ faktem przyjęcia chrztu, mówią, że właśnie ten sakrament jest momentem, w którym dokonuje się owo duchowe oświecenie (por. 10,32) i to pojęte zarówno jako doktrynalne pouczenie, - z chrztem bowiem łączył się cały, długi proces stopniowego wtajemniczania, - jak też pojęte jako wewnętrzna łaska Boża ${ }^{9}$. To duchowe oświecenie tradycja do tego stopnia wiązała $\mathrm{z}$ momentem przyjęcia chrztu, że sam ten sakrament został nazwany phōtismós ${ }^{\mathbf{1 0}}$.

Chrześcijanie zakosztowali dalej daru niebieskiego, czyli otrzymali pokarm dla duszy.

Istnieje wielka pokusa, by za takimi egzegetami jak Haimon z Auxerre, Faber Stapulensis, Estius przyjąć, że tym darem Bożym jest Eucharystia. Sam czasownik , kosztować" dobrze harmonizowałby w połączeniu z Eucharystią, zwłaszcza, że w Dziejach Apostolskich występuje w takim właśnie kontekście. ${ }^{11}$ Zresztą przypomnienie chwiejącym się $\mathrm{w}$ wierze i zaniedbującym religijne praktyki $(10,25)$ adresatom właśnie Eucharystii, daru Bożego w najwyższym stopniu i pośród wszystkich darów naczelnego, byłoby jak najbardziej właściwe. Takiej intepretacji nie pozwala jednak przyjąć stojące przed wszystkimi imiesłowami określającymi rodzaj Bożego daru, a tym samym do wszystkich odnoszące się słowo hapaks. Liczebnik ten charakteryzuje daną czynność jako jeden raz dokonaną i to w ten sposób, że nie może być więcej powtórzona. Stąd też nie może tutaj być mowy o Eucharystii, ani też o żadnym takim akcie, który może być ponawiany. Należałoby raczej przyjąć, że słowem dōreá nazwał autor wszystkie po prostu istotne elementy wchodzące w skład życia nadprzyrodzonego, które są skutkiem przede wszystkim sakramentu chrztu, czyli krótko mówiąc chodzi o nadprzyrodzoną łaskę Bożą wziętą ogólnie.12

6 Ef 1,$18 ; 3,9$.

7 王 16, 8; J 12, 36; 1 Tes 5,5 .

82 Kor $4,4$.

9 Po tej linii rozumowania idzie również Peszitta syr., która zamiast phōtisthéntas ma: Ima'muditho néth - : którzy zstąpili do chrztu. S. Each, Pismo Swięte Nowego Testamentu, X: List do Hebrajczyków, Poznań 1959, comm. ad loc.

${ }_{10}$ Termin ten występujący jako synonim chrztu spotykamy po raz pierwszy u św. Justyna, Apol. 1, 61. 65; Dial. 122. S. Each, dz. cyt. comm., ad loc.

$11 \mathrm{Dz} 20,11$; por. J $6,31 \mathrm{n}$.

12 Zwłaszcza, że czasownik didōmi i jego pochodne mówią o udzielanych przez Boga dobrach nadprzyrodzonych, por. Ef 4, 8; Jk 1, 17; Rz 5, 16; Ef 2, 8. 
Zresztą dla naszego tematu obojętną jest rzeczą, czy przyjmiemy, że chodzi tu o jakiś konkretny rodzaj łaski bożej, czy też o dar Boży pojęty całościowo. Ważne jest natomiast stwierdzenie, że terminem tym oznaczył autor coś, co wchodzi w skład normalnego nadprzyrodzonego wyposażenia człowieka, coś, co chrześcijanie posiadają właśnie dzięki temu, że są chrześcijanami. Według C. Spicqa ${ }^{13}$ określenie to jest terminem technicznym, posiadającym taki sam zakres pojęciowy, jaki posiada słowo charis, a więc podobnie jak ono zawierającym odcień darmowości i życzliwości. Bliższe określenie tego daru: niebicski wskazuje na jego pochodzenie od Boga. Chrześcijanie tego daru zakosztowali. Czasownik geúomai znaczy kosztować, jeść w sensie ścisłym, ale oznacza też doświadczać, badać, doznać, dojść do czegoś doświadczalnie, brać w czymś udział ${ }^{14}$. Używając tego słowa chciał autor podkreślić osobisty, a nadto jednorazowy (aoryst!) charakter doświadczenia, które stało się udziałem chrześcijan.

Dalszym przywilejem chrześcijan jest ich uczestnictwo w Duchu Swiętym. Sformułowanie „stać się uczestnikiem Ducha Swiętego" posiada wiele znaczeń. Może bowiem odnosić się zarówno do chrztu ${ }^{15}$ jak i obrzędu wkładania rąk ${ }^{16}$, a może też oznaczać wyjątkową nadprzyrodzoną siłę, którą często ludzie byli napełniani, czyli charyzmaty. ${ }^{17}$

Chrześcijanie przyswoili sobie również „,piękne słowo Boże”. Słowem tym jest zapewne Ewangelia ${ }^{18}$, owa Dobra Nowina zwiastująca ziszczenie się Bożych obietnic i będąca kierunkowskazem dla ludzi.

Zakosztowali wreszcie, czyli osobiście doświadczyli mocy przyszłego wieku. „Mocami przyszłego wieku” nie nazywa z całą pewnością autor życia niebieskiego, błogiego oglądu, którym cieszą się święci w niebie.

13 L'Épitre aux Hébreux, Paris 21953, 150.

14 Por. F. Zorell, Lexicon graecum NT, Parisiis, 250.

$151 \mathrm{Kor} 12,13$; Tt $3,5 \mathrm{n}$.

$16 \mathrm{Dz} 19,6 ; 8,14$ n., por. też 2 Kor 1, 21 n.; Ef $1,13$.

$17 \mathrm{Dz} 2$, 4. 15 n.; 4, 8. 31 .

18 Niektórzy egzegeci np. J. Bonsirven, L. Venard przeciwstawiając rzeczownikowi logos termin rhêma sugerują, że autor używając tego drugiego miał na myśli mowę Boga wewnątrz duszy, prywatne objawienia, charyzmat proroctwa, lub dar języków. Przeciwko takiemu jednak ujęciu C. Spicq przytoczył przekonywujące argumenty:

a. oba terminy są w LXX przekładem jednego tylko hebrajskiego słowa dobar i mogą być synonimami.

b. liczba pojedyncza rhēma przemawia za tlumaczeniem wedle którego chodzi tu o całościowo pojęte orędzie ewangeliczne.

c. sformułowanie to jest odpowiednikiem nie występującego rzeczownika euaggélion i jest równoznaczne $\mathrm{z}$ epignōsis alêtheias $(10,26)$, oraz lalēthèn hypō theô̂ dià Christoû $(1,1 ; 2,3)$.

d. przyjęcie Ewangelii łączy się ściśle z oświeceniem i uczestnictwem w Duchu Swiętym.

e. na korzyść tej interpretacji przemawia także połączenie w kontekście z "mocami", a zwłaszcza ze ,,światem przyszłym" (por. 1, 3; J 3, 34; $\mathrm{Dz} 10,44 ; \mathrm{Rz} 1,16)$. 
Nie może tak być $z$ tego powodu, że podobnie jak poprzednio występuje tu czas przeszły, mianowicie imiesłów aorystu geusamenous, co wskazuje, że moc ta nie tylko może być dostępna dla ludzi żyjących na ziemi ale faktycznie stała się udziałem chrześcijan, już jej bowiem doświadczyli. Moc ta nie złączyła na stałe i w sposób nierozerwalny chrześcijan z Królestwem niebieskim, z Bogiem, gdyż każdy człowiek stoi przed niebezpieczeństwem jej utraty. $(2,1 ; 3,12$ n. 6,5 n. 10, 26; 12, 15.). Są to jednak moce eonu przyszłego, a więc chociaż obecne są w teraźniejszości, w tym doczesnym porządku rzeczy, to jednak genetycznie do niego nie należą.

Zestawienie ostatniej części omawianego zdania z przeanalizowanymi już poprzednio poszczególnymi jego członami pozwala nam wnioskować, że aczkolwiek autor używa tu różnych sformułowań, to jednak w gruncie rzeczy wyrażenia te są synonimami. Nie wymienia bowiem w tym wypadku poszczególnych rodzajów łaski - nawet słowo dōron nie oznacza tu tych szczególnych łask, które teologia nazwała darami Ducha Świętego - lecz mówi o całości Bożego daru, o łasce Bożej w ogóle, nie wyłączając dobrodziejstwa tego, jakim jest słowo Boże zawarte w Ewangelii. Możemy powtóre stwierdzić, że dar Boży o którym mowa w interesującym nas zdaniu jest wynikiem przede wszystkim chrztu - nawet jeśli chodzi o „piękne słowo Boże”, którego zakosztowali chrześcijanie, to wiadomo, że najintensywniej zapoznawali się z nim w związku z przyjęciem tego właśnie sakramentu. Wymienione dary obejmują więc zarówno łaski, które są skutkiem chrztu, jak i te, do których chrzest otwiera człowiekowi drogę. Krótko mówiąc pod pojęciami tymi kryje się przede wszystkim ta rzeczywistość, którą teologia nazwie łaskami sakramentalnymi.

Być może, że autor pisząc „moce przyszłego wieku” miał na myśli nadzwyczajne zjawiska, cudy i charyzmaty, które zwiastują nadejście ery mesjańskiej bynajmniej nie sporadycznie towarzyszyły życiu Kościoła na tym etapie. Bóg bowiem uwierzytelnił zbawienie „cudami, znakami przedziwnymi, różnorakimi mocami i rozdzielaniem Ducha Świętego według swej woli" (por. 2, 4). Pogląd taki nie jest wykluczony, co więcej dziwną by było rzeczą, gdyby autor nie wykorzystał takiego bądź co bądź argumentu ad hominem dla przekonania i umocnienia chwiejącego się $\mathrm{w}$ wierze człowieka. Trzeba jednak pamiętać. że nadzwyczajne zjawiska choć z całą pewnością były wówczas bardzo częste, to nie aż tak, by autor mógł odwoływać się do osobistego doświadczenia każdego czytelnika Listu.

Po tym wszystkim można postawić jedno jeszcze twierdzenie, że mianowicie wyrażenie ,zakosztowali... mocy przyszłego wieku” jest rekapitulacją treści zawartej w poprzedzających je członach analizowa- 
nego zdania, z tym zastrzeżeniem, że każdy z terminów występujących w tym zdaniu, mówi jak stwierdziliśmy, o Bożym darze podkreślając jakiś szczególny jego aspekt. Wyrażenie „moce przyszlego wieku” mówi o aktywnym, dynamicznym charakterze tego daru. Do istoty bowiem mocy należy działanie, aktualizowanie się.

\section{NOWE PRZYMIERZE WEĄCZA CHRZESCIJAN W SFERE SWIATA NIEBIESKIEGO}

Czytając list do Hebrajczyków można z łatwością stwierdzić, że autor ciągle $\mathrm{z}$ uporem, by nie powiedzieć z obsesją, wraca do porównywania Nowego Przymierza ze Starym i na tym tle wykazuje wielkość zapoczątkowanej przez Chrystusa nowej epoki w historii zbawienia. Głównym, obok wielu innych, elementem charakteryzującym i wyróżniającym tę epokę, jest obecność w niej „dóbr przyszłych”, możność partycypacji człowieka w ,świecie przyszłym" już w czasie jego życia na ziemi. Zagadnienie to $\mathrm{w}$ odmiennej nieco szacie słownej jest przedmiotem rozdziału dwunastego. „Nie przystąpiliście bowiem do dotykalnego i płonącego ognia, do mgły, do ciemności i burzy ani też do grzmiących trąb i do takiego dźwięku słów, iż wszyscy, którzy go słyszeli, prosili, aby do nich nie mówił ... Wy natomiast przystąpiliście do góry Syjon, do miasta Boga żyjącego, Jeruzalem niebieskiego, do niezliczonej liczby aniołów, na uroczyste zebranie, do Kościoła pierworodnych, którzy są zapisani w niebiosach, do Boga, który sądzi wszystkich, do duchów sprawiedliwych, które już doszły do celu, do pośrednika Nowego Testamentu - Jezusa, do pokropienia krwią, która przemawia mocniej niż [krew] Abla" (12, 18 n.) ${ }^{19}$.

W powyższych wierszach zawiera się owo słynne przeciwstawienie Starego i Nowego Przymierza przy pomocy obrazowej antytezy Synaj-Syjon. Te dwie góry, które były miejscem kontaktu Boga z narodem wybranym są symbolami obu Przymierzy. Symbolem Starego Przymierza jest góra Synaj, na niej bowiem zostało ono zawarte. Syjon zaś jest zgodnie z proroczymi zapowiedziami miejscem intronizacji przez Jahwe Mesjasza, ${ }^{20}$ oraz areną największych wydarzeń mesjańskich. ${ }^{21}$

Nim przejdziemy do bardziej szczegółowej analizy warto zwrócić uwagę na ciekawy sposób, jakim posłużył się autor przedstawiając te dwie rzeczywistości. Przymierze Stare, zawarte na górze Synaj opisuje on od strony czysto zjawiskowej, zewnętrznej. Przedstawia mianowicie

19 Podobna myśl zawarta jest również w Ef 2, 6 .

20 Ps 2, 6.

${ }_{21}$ Iz 2, 2; 11, 9; 25, 6; $\mathrm{Mi} 4,1$; Za 14, 4. Temat ten podejmuje również Nowy Testament, por. Gal 4, 24 n.; Ap 14, 1 n. 
różnorodne, groźne zjawiska przyrodnicze, jakie towarzyszyły jego zawarciu, pomijając zupełnie jego treść i skutki. Widocznie chce autor, by czytelnicy Listu, którzy zresztą dobrze znali to Przymierze, wnioskowali o jego wewnętrznej treści z zewnętrznych, a pełnych grozy zjawisk towarzyszących jego zawarciu. Odwołując się do posiadanych przez odbiorców Listu wiadomości, autor wywołał u nich obraz, który zwłaszcza w zestawieniu z opisem Nowego Przymierza musiał pobudzać nawróconych Izraelitów do oceny porównywanych rzeczywistości.

Przeciwstawione Staremu Przymierze Nowe jest zaś pokazane od strony jego skutków. Idąc za myślą autora stwierdzamy, że zarówno Izraelici, jak i chrześcijanie przystąpili w swoim czasie, czyli zawarli z Bogiem przymierze. Zarówno w odniesieniu do Izraelitów, jak i chrześcijan używa tego samego słowa proselēlýtate „doszliście”, ,przystąpiliście".

Słowo to ma jednak nieco inne znaczenie $\mathrm{w}$ odniesieniu do narodu wybranego, a inne jeśli chodzi o chrześcijan. W stosunku do żydów obok znaczenia przenośnego, to znaczy „,zawarliście przymierze”, może oznaczać faktyczne materialne zbliżenie się, fizyczną obecność pokolenia, które jako reprezentant całego narodu, było pod Synajem świadkiem zawarcia Przymierza. Pokolenie to przeżyło całą grozę dziwnych zjawisk towarzyszących temu wydarzeniu. Wiedzieli o tym wszyscy Izraelici i do tej ich wiedzy odwołal się autor.

„Przystąpienie” chrześcijan ma natomiast inny charakter. Samo słowo proselellýtate jest użyte $\mathrm{w}$ odniesieniu do nich tylko w przenośnym znaczeniu, oznacza bowiem, jak dowiadujemy się z dalszych słów autora, wejście w inny, duchowy świat.

O ile Synaj - symbol Starego Przymierza, wzbudzał groźnymi zjawiskami wśród narodu wybranego popłoch, który raczej oddalał uczuciowo od Boga, niż pociągał, o tyle Nowe Przymierze, którego kontrahentami są chrześcijanie daje przystęp do Boga, do Chrystusa, daje zbawienie i życie wieczne. ${ }^{22}$ Już samo przeciwstawienie Synaj-Syjon wskazuje bardzo duchowy charakter tej rzeczywistości, w której uczestniczą chrześcijamie. Góra Syjon oprócz łączenia jej z wydarzeniami mesjańskimi, uważana była za mieszkanie Boga. Na niej to Jahwe według proroków miał być przez całą ziemię widziany jako niezwykłe światło. ${ }^{23}$

Wyrażenie ,góra Syjon" można traktować jako określenie samej świątyni jerozolimskiej, która w szczególny sposób była mieszkaniem Jahwe. ${ }^{24}$ Dziẹki Nowemu Przymierzu chrześcijanie stali się mieszkańcami „miasta Boga żyjącego”, „Jeruzalem niebieskiego”. Pojęcie „Jeruzalem nie-

22 Por. Gal 4, 24 n.; Ef 2, 5 n.; 3, 12.

23 Por. Iz 2, 3; 28, 16; 60, 1 n.; Jl 2 , 1 n.; 3, 1 n.; 4, 17; Ps 49 (50), 2.

$241 \mathrm{Mch}^{\prime} 4,37.46$. 
bieskie" pochodzi z apokaliptyki żydowskiej, gdzie służyło jako określenie wieczności Bożej, w której uczestnictwo mieć będą ludzie. Zostało ono podjęte przez św. Pawła ${ }^{25}$ i św. Jana ${ }^{26}$. Dla Izraelitów, którzy raczej pozbawieni byli zmysłu filozoficznego, obce było rozróżnienie między czasem a wiecznością. Życie przyszłe w wieczności utożsamiali z nieograniczonym pod względem czasowym trwaniem Jeruzalem nowego, przyszłego lub niebieskiego. Przymiotniki te miały za zadanie podkreślić, ze chodzi o kontynuację ziemskiej stolicy tylko pod względem czasowym, ale nie pod względem jakościowym, gdyż w nowym Jeruzalem miały zostać zrealizowane wszystkie obietnice Boże.

Uwolnienie od grzechów, łączność z Bogiem, pokój, oraz element stalości i trwałości, to najważniejsze cechy charakteryzujące pobyt w no-wym mieście.

Do takiego właśnie Jeruzalem przystąpili chrześcijanie, czyli powiększają już w jakiś sposób liczbę jego obywateli.

Myśl swoją precyzuje autor jeszcze dokładniej kiedy pisze, że wierni przystąpili ,do niezliczonej liczby aniołów, na uroczyste zebranie, do Kościoła pierworodnych, którzy są zapisani w niebiosach". Aniołowie według Starego Testamentu, otaczając tron Boży stanowią niebieski dwór. Oni to według Listu do Hebrajczyków są współpracownikami Boga w dziele zbawiania ludzi. Są bowiem duchami służebnymi $(1,14)$, a więc zadaniem ich jest spełnianie publicznej służby mającej na celu niesienie ludziom dążącym do zbawienia duchowej, religijnej pomocy. W szereregach uroczystego zgromadzenia aniołów znaleźli się teraz dzięki Nowemu Przymierzu wierzący chrześcijanie i tworzą razem z nimi jedną pod pewnym względem społeczność. ${ }^{27}$

Różne są zdania egzegetów co do znaczenia, jakie należy nadać wyrażeniu „Kościół pierworodnych”. Jedni sądzą, że chodzi tu o aniołów. ${ }^{28}$ Byłoby to wówczas powtórzeniem poprzedniej myśli. Według innych chodzi raczej o powszechne zgromadzenie wszystkich wiernych chrześcijan wszystkich czasów, którzy są członkami społeczności Kościoła. ${ }^{29}$ Godny podkreślenia jest jeszcze fakt, że autor nazywa chrześcijan pierworodnymi. Tytuł ten równoznaczny często z "umiłowany" i odnoszący się w Nowym Testamencie przede wszystkim do Chrystusa

25 Gal 4, 26.

26 Ap 3, 12; 21, 2. 10.

27 Treść tę znajdujemy również w listach Pawłowych, gdzie jest mowa o pewnego rodzaju jedności, jaka zaistniała między ludźmi i aniołami dzięki Chrystusowemu odkupieniu i w Chrystusie jako Głowie, por. Kol 1, 20 ; Ef 1, 10. Podobne, jak ten, obrazy zawiera Ap 19, $10 ; 22,9$. Solden.

${ }_{28}$ Tak Ojcowie greccy oraz W. Michaelis, J. H. Kurtz, A. Lemonnyer, H. vor

${ }_{29}$ J. Chryzostom, Ekumeniusz, Teofilakt, Klemens Aleks., F. Delitzsh, A. Westcott, W. H. Ferrar, J. Moffat, A. Médebielle, J. Bonsirven. 
$(1,6),{ }^{30}$ został tu rozszerzony na tych wszystkich, którzy są uczestnikami Chrystusa $(3,14)$.

O istocie tej społeczności i jej eschatologicznym charakterze mówi dalsza część zdania, że mianowicie imiona pierworodnych zapisane są w niebie. ${ }^{31}$ Gradacja przywilejów, które stały się udziałem chrześcijan idzie dalej. Chrześcijanie przystąpili, czyli zbliżyli się duchowo do samego Boga-Sędziego. Jest bardzo znamienną rzeczą, autor spośród wielu tytułów wybiera akurat tytuł Sędziego. Chrześcijanie wiedzieli dobrze, że droga do zbawienia, do pełnego osiągnięcia ,dóbr przyszłych" prowadzi przez Sąd Boży. Swiadomość zaś czekającego Sądu musi każdego napawać lękiem i niepewnością. Autor pociesza więc chrześcijan myślą, że Boga-Sędziego mają jakby po swojej stronie, bo mają w Nim uczestnictwo i dzięki temu znajdują się w zupełnie wyjątkowej sytuacji. Skoro raz uzyskali przystęp do Boga, to tym samym, o ile, rzecz prosta, wytrwają przy Nim, zapewnili sobie niejako pomyślny wynik sądu.

"Przystąpili dalej do „duchów sprawiedliwych”, które już doszły do celu. Sprawiedliwymi, którzy doszli do celu są święci, którzy doświadczają pełni skutków Chrystusowego odkupienia (10, 14; 11, 39 n.). Chrześcijanie są właśnie tymi, którzy zdążają do wskazanego im przez wiarę celu. Każdy, kto na tę drogę wstąpil, wnet przekonał się, że nie jest to sprawa łatwa. Stąd zniechęcenie, wahania, czy nawet odstępstwa. Tymczasem autor natchniony pisze swoim adresatom, że oni przystąpili, czyli mają już udział z tymi, którzy osiągnęli zbawienie. Chrześcijanie żyjący na ziemi należą do ich liczby, bo dysponują wszystkimi środkami potrzebnymi do osiągnięcia tego celu.

Czytamy wreszcie, że chrześcijanie przystąpili do „,pośrednika Nowego Testamentu - Jezușa, do pokropienia krwią, która przemawia mocniej niż [krew] Abla." Chrystus znajduje się w niebie (4, 14; 6, 20), zasiadł przecież ,,po prawicy tronu Majestatu w niebiosach, jako sługa świątyni i prawdziwego przybytku zbudowanego przez Pana, a nie przez człowieka” (8, 1 n.), ,,przez własną krew wszedł raz na zawsze do Miejsca Świętego” $(9,12)$, wszedł „do samego nieba, aby teraz wstawiać się za nami przed obliczem Boga" (9, 24).

Przystąpili więc chrześcijanie do Chrystusa znajdującego się w niebie i stali się uczestnikami skutków jego krwawej ofiary, albowiem przystąpili „do pokropienia krwią". Termin ten chociaż nawiązuje do czynności Mojżesza, gdy na Synaju krwią ofiar przypieczętował zawarte co

30 Por. Kol 1, 15. 18; Ap 1, 5. Pierworodnym jest też czasem nazwany przez Boga Izrael, por. Wj 4, 22; Jer 31, 9.

31 Znajdującą się $\mathrm{w}$ niebie księgę $\mathrm{z}$ imieniami wybranych zna zarówno tradycja izraelska, jak i chrześcijańska, por. Wj 32, 32; Ps 68 (69), 29; Iz 4, 3; Dn 12, 1; 玉k 10, 20; Flp 4, 3; Ap 13, 8; 17, 8; 21, 27. 
dopiero Przymierze, to jednak odnosi się do Krwi Chrystusa, którą zapieczętowane zostało Nowe Przemierze.32 Chrześcijanie stali się tedy uczestnikami dóbr będących owocem zbawczej arcykapłańskiej ofiary Chrystusa. Wymowę i znaczenie krwi Chrystusa podkreślił autor przez zestawienie jej z krwią sprawiedliwego Abla. Podobnie jak krew Abla wołała o sprawiedliwość, tak jeszcze mocniej krew Chrystusa woła, ale nie o pomstę, lecz o przebaczenie $(9,12$ n.; 10, 29; 13, 12), posiada ona przecież walor pojednawczy, dokonuje oczyszczenia $\mathrm{z}$ grzechów.

Przejęty nadprzyrodzoną rzeczywistością autor nagromadził w omawianym zdaniu wiele wspaniałych określen, by w różnych aspektach przedstawić tę samą rzeczywistość, mianowicie eon przyszły. Ukazał w ten sposób całe bogactwo, złożoność i nieodparcie pociągającą moc życia niebieskiego, zwłaszcza, że wskazał wyraźnie, iż chrześcijanie przez antycypację realnie już w tym życiu uczestniczą. Przystąpiwszy już do Nowego Przymierza, weszli rzeczywiście w obręb świata przyszłego.

Dla całości trzeba jeszcze wskazać na moment, w którym człowiek przystępuje do tego Przymierza, którego symbolem jest góra Synaj, a tym samym kiedy staje się uczestnikiem świata przyszłego, niebieskiego życia? Odpowiedzieć na to pytanie można po przeanalizowaniu czasownika ,przystąpiliście”. Z gramatycznego punktu widzenia jest to perfectum, a więc czas, który według reguł gramatyki greckiej oznacza czynność dokonaną w przeszłości, lecz w ten sposób, że skutki tej czynności wciąż trwają.

Momentem zawarcia przez człowieka przymierza i wejścia w sferę rzeczy niebieskich jest bez wątpienia sakrament chrztu. ${ }^{33}$ Udowodnienie tego twierdzenia nawet na gruncie samego tylko Listu do Hebrajczyków nie jest rzeczą trudną. Analizowany tekst mówi między innymi o uczestnictwie wiernych $\mathrm{w}$ pokropieniu krwią Chrystusową czyli o udziale w skutkach zbawczego dzieła Chrystusa. Chrześcijanie zostali pokropieni krwią Chrystusową, która ma moc oczyszczającą i uświęcającą (9, 13 n.). Oczyszczenie od wszelkiego zła, według tego samego Listu dokonuje się w momencie chrztu $(10,22)$. Oczyszczająca zatem i uświęcająca moc Chrystusowej krwi dotyka człowieka i staje się skuteczna w tym właśnie sakramencie. Możemy więc wysunąć twierdzenie, że termin ,pokropienia krwią" odnoszący się w pierwszym rzędzie do przelania krwi Chrystusowej na krzyżu, obejmuje również zbawienie w akcie dokonywania się, czyli aplikację skutków Odkupienia, która dokonuje się w akcie chrztu. Wcześniej już zostało też wykazane, że nadprzyro-

32 W formułach konsekracji drugiej postaci u synoptyków znajdują się słowa, które wypowiedział Mojżesz kropiąc lud ofiarną krwią, por. IMt 26, 28; Mk 14, 24; Łk 22, 20; Wj 24, 8.

33 Por. Rz 6, 3 n.; Kol 2, 12; Tt 3, 5; Ell 5, 26; 1 P 3, 21 . 
dzone dary nazwane przez autora „mocami przyszłymi” wiążą się ściśle z przyjęciem chrztu.

Dzięki przystąpieniu do góry Syjon, czyli przyjęciu przez chrzest Nowego Przymierza chrześcijanie weszli, chodzi o fakt dokonany, w sferę niebieskiego życia i w niej trwają. Posiadają w stanie zaczątkowym udział w niebie i jeśli sami nie zaprzepaszczą tej szansy, to nic nie stoi na przeszkodzie w osiągnięciu przez nich całej pełni owych dóbr. Czasownik ,przystąpiliście" podobnie jak poprzedni „zakosztowali” wskazuje na cząstkowy, czy też raczej zaczątkowy charakter uczestnictwa w „,dobrach przyszłych”. Przeanalizowany tekst jest, jak widać, wspaniałym rozwinięciem i do pewnego stopnia wyjaśnieniem poprzednio omawianego, pozwala bowiem jaśniej zrozumieć naturę owych urzeczywistnionych „,dóbr przyszłych”.

\section{„DOBRA PRZYSZEE” JAKO OWOC ZBAWCZEJ DZIAEALNOSCI} PODPORZĄDKOWANE SĄ CHRYSTUSOWI

W Liście do Hebrajczyków znajdują się jeszcze dwa teksty które expressis verbis mówią o rzeczywistości przyszłej w kategoriach teraźniejszości. Wiążą one fakt uobecnienia ,świata przyszłego” z soteryjną działalnością Chrystusa.

„Ale Chrystus zjawiwszy się jako arcykapłan dóbr przyszłych przez wyższy i doskonalszy, i nie ręką - to jest nie na tym świecie uczyniony przybytek, ani przez krew kozłów i cielców, lecz przez własną krew wszedł raz na zawsze do Miejsca Świętego, zdobywszy wieczne odkupienie" $(9,11-12)$. Trzeba na wstępie zaznaczyć, że niektóre poważne rękopisy mają nieco inny tekst. Mianowicie zamiast „dóbr przyszłych" mellontōn agathōn mają "dóbr już obecnych." genomenōn ${ }^{34}$. Nie jest wykluczone, że w czasie przepisywania zaszła pomyłka i powtórzona została część bezpośrednio przed tym stojącego słowa paragenomenos, bardziej jednak prawdopodobne jest przypuszczenie, że w czasie przepisywania skryba „ulepszył” tekst rozumując prawidłowo, że „dobra przyszłe" to te, które uobecnił Chrystus ${ }^{35}$. To zaś jeszcze bardziej potwierdzałoby przedstawiony tu tok rozumowania.

Wracając do naszego tekstu stwierdzamy, że autor znowu, jak to miało miejsce poprzednio, dokonuje we wiadomym już celu porównania Nowego Przymierza ze Starym, lub ściślej mówiąc instytucji Starego Przymierza z Arcykapłanem Przymierza Nowego. W poprzedzających

34 mellontōn mają: S A I K L P Vg, arm, kopt i za tym idzie Eus, Cyr Al, Chryz, Merk, Grundmann, Käsemann, Michel.

genomenōn: $\mathrm{P}^{46} \mathrm{BD} 16111739$ 2005, ital, syr, i za tym idzie Oryg, Cyr Jer, W-tt, Nestle, Windisch.

35 Sugestię taką podsunął mi w czasie konsultacji o. prof. A. Jankowski OSB. 
nasze zdanie wierszach autor per longum et latum opisuje cały kult starotestamentalny, dając szczegółowy obraz najważniejszych przedmiotów przeznaczonych do służby Bożej w tym okresie z uwzględnieniem ich symboliki i typologicznego znaczenia. Zaraz potem przechodzi do wykazania różnych słabych stron tychże liturgicznych czynności, materialnego i przygotowawczego charakteru starego kultu. Swiątynia i cały związany z nią aparat świętych czynności były obrazem parabolē ,na czas teraźniejszy" tego, co miało dopiero nadejść. Trzeba tu zaznaczyć, że termin „czas teraźniejszy (tōn kairōn enestēkóta) nie oznacza Nowego Testamentu, lecz odnosi się do Starego, w takim znaczeniu używali go prorocy. Z kontekstu widać, że posłużył się nim autor listu do Hebrajczyków jako terminem technicznym, co jest tym łatwiejsze do odczytania, że czasowi temu wyraźnie przeciwstawiony jest „czas naprawy” (diorthōseos). Otóż obrzędy „czasu teraźniejszego”, czyli starotestamentalna liturgia udziela oczyszczenia zewnętrznego, prawnego, ale nie dosięga wnętrza czlowieka i nie jest zdolna dokonać $w$ nim wewnętrznej przemiany, zgładzić jego grzechów, pojednać go z Bogiem. Rzeczywistość nowa nie tylko nie zawiera tych braków, którymi odznaczał się stary porządek rzeczy, ale jest pod każdym względem doskonała i skuteczna, bo Chrystus ,przez własną krew wszedł raz na zawsze do przybytku zdobywszy wieczne odkupienie" $(9,12)$. Rękojmią i pieczęcią wielkości i skuteczności nowego porządku rzeczy jest jego sprawca Jezus Chrystus. On to właśnie zjawił się jako ,arcykapłan dóbr przyszłych".

Przez słowo ,zjawił się” autor chce podkreślić historyczny moment przybycia Chrystusa na ziemię (imiesłów aorystu!). „Chrystus jako przychodzący $\mathrm{z}$ innego świata, wszedł na scenę w decydującym momencie historii, by odegrać swą rolę ... Jego kapłańska funkcja, której celem było zdobycie zbawienia, jest $\mathrm{z}$ istoty swej eschatologiczna". ${ }^{36}$ On więc jest sprawcą tych dóbr. Dzięki wypełnieniu przez Chrystusa Jego arcykapłańskiego posłannictwa „dobra przyszłe" zaistniały w nowej ekonomii zbawienia i stały się dostępne dla ludzi. Nic więc dziwnego, że Chrystusowi poddał Ojciec ,świat przyszły”: „Nie aniolom bowiem poddał przyszły świat...” Kontekst jest jasny: tym, który poddał „przyszły świat" jest Bóg Ojciec, tym zaś któremu ten świat został poddany jest Jezus Chrystus.

Tym razem znowu, jak poprzednio, chodzi autorowi o wykazanie przewagi Nowego Testamentu nad Starym. I to jest bardzo znamienne, świadczy bowiem do jakiego stopnia zrealizowane już dobra przyszłe stanowią konstytutywną część nowej epoki zbawczej. Rozstrzygającym 
argumentem za zdecydowaną wyższością Nowego Przymierza (sōtēria) nad Starym (logos) jest godność Pośrednika. W przekonaniu Izraelitów, wielkość Starego Przymierza wynikała stąd, że zostało ono zawarte za pośrednictwem aniołów ${ }^{37}$. Nawiązując do tego poglądu stwierdza, że to właśnie co dla nich było powodem chluby i świadectwem wielkości zawartego przez nich Przymierza jest czymś znikomym w porównaniu z Pośrednikiem Przymierza Nowego - Jezusem Chrystusem. Dalsza argumentacja idzie po tej linii, że jeśli łamiących Stare Przymierze spotykały surowe kary, to cóż dopiero tych, którzy przekraczają Nowe Prawo. Kara będzie proporcjonalna do wielkości odrzuconych darów. „Jeśli bowiem objawiona przez aniołów mowa była mocna, a wszelkie przekroczenie i nieposłuszeństwo otrzymywało słuszną zapłatę, jakże my unikniemy [kary], jeśli nie będziemy się troszczyć o tak wielkie zbawienie? Było ono głoszone na początku przez Pana, a umocnione $u$ nas przez tych, którzy je słyszeli" (2, 2; por. 10, 28 n.).

To właśnie nowe ogłoszone przez Pana Przymierze nazywa autor „światem przyszłym”, który podporządkowany został przez Boga Synowi. Znowu więc spotykamy zasygnalizowany na początku paradoks polegający na tym, że „przyszły świat” Bóg poddał Chrystusowi.

„Poddał" wyrażone jest w aoryście, chodzi więc o czynność raz w przeszłości dokonaną. Na określenie zaś „świat” posłużył się autor terminem oikoumenè, by podkreślić, że ma na myśli ten obecny zamieszkany przez ludzi świat. ${ }^{88}$ Mówi więc autor o obecnym doczesnym porządku rzeczy ${ }^{39}$ nazywając go przyszłym. Kontekst pozwala nam postawić twierdzenie, że ,świat przyszły” utożsamia się z rzeczywistością nazwaną ,tak wielkie zbawienie” (2, 3), o którym autor pisze, że trzeba się o niego troszczyć. Chodzi więc w tych wyrażeniach o zbawienie w akcie stawania się. Słowo „przyszły” oznaczałoby więc mniej więcej tyle co ,zbawiony”, czyli posiadający to wszystko, co uzyskał dzięki odkupieniu, a więc wyposażony w zbawienne środki. Reasumując należy stwierdzić, że w zdaniu tym nie ma mowy o tym ,świecie”, który za-

37 Pwt 33, 2 (LXX); oraz Hen 79, 59; Jub 1, 27.

Teologia żydowska przyznawała aniołom rządy nad narodami: Pwit 32, 8 (LXX); Syr 18, 17; Hen 89, 70. 71. 76; Jub 35, 17; 15, 31 i poddawała elementy kosmosu: gwiazdy, deszcze, wiatry pod ich kierownictwo, por. Hen 60, 15 n.; 20, 4; Jub 2, 2. Por. J. Bonsirven, Le judaisme palestinien au temps de Jésus Christ, I: La théologie dogmatique, Paris 1934, 230-239. Zob. też Dn 10, 13. 20; 12, 1; Dz 7, 38. 53; Gal 3; 19.

38 Por. Mt 24, 14; Łk 4, 5; 21, 26; Rz 10, 18; Ap 3, 10;16, 14. oikoumenē jest tym miejscem, do którego wszedł przez Wcielenie Syn ( $\operatorname{Hbr} 1,6)$ i gdzie dokonuje się zbawienie.

${ }_{39}$ Użyty tu termin ,porządek rzeczy” podkreśla, że nie chodzi wyłącznie o świat materialny, lecz o całą, a więc i nadprzyrodzoną rzeczywistość zamkniętą w czasie i przestrzeni. 
istnieje dopiero po Paruzji Chrystusa, kiedy to wszystko będzie Mu w sposób widzialny podporządkowane $(2,8)$, czyli nie chodzi tu o życie niebiańskie, lecz o zbawienie dokonujące się od momentu odkupienia począwszy, aż po powtórne przyjście Chrystusa. Termin ten oznacza więc rzeczywistość właściwą czasom mesjańskim, które są już przeniknięte ,siłami wieku przyszłego".

\section{WNIOSKI TEOLOGICZNE}

WZGLĘDNE, CZASOWE ZNACZENIE SEOWA „PRZYSZEY”

Biorąc pod uwage to, co dotąd zostalo na temat eschatologii Listu do Hebrajczyków napisane, musimy stwierdzić, że słowo ,przyszły" wyraża rzeczywistość o wiele bardziej złożoną, niż kwestia przeszłości, teraźniejszości, czy przyszłości. Ramy doświadczanego przez nas czasowego następstwa rzeczy są tu niewystarczające dlatego, że nadprzyrodzona rzeczywistość, która w nich również się mieści wykracza daleko poza nasze doświadczenie i powoduje całą tę złożoność. Nie znaczy to jednak bynajmniej, by omawiana przydawka nie posiadała w tych miejscach pierwotnego i właściwego $\mathrm{z}$ punktu widzenia semantyki znaczenia. Owszem wyraz ten, jak niżej zobaczymy, określa rzeczywistości, do których się w zdaniu odnosi jako przyszłe, czyli późniejsze w stosunku do poprzedniego okresu, kiedy to były przedmiotem obietnicy i oczekiwania. Posługując się w takim kontekście kategoriami czasowymi, trzeba zawsze mieć na uwadze rozwój zbawczego planu Bożego z uwzględnieniem najistotniejszych cech należących do poszczególnych jego etapów. Wynika to jasno $\mathrm{z}$ następującego tekstu: „Prawo bowiem posiadając tylko cień przyszłych dóbr, a nie sam obraz rzeczy, przez te same ofiary, corocznie ciągle składane, nie może nigdy udoskonalić tych, którzy się zbliżają." $(10,1)$.

By należycie rozumieć myśl zawartą w tym wierszu, należy najpierw rozróżnić między terminami „,ień” (skii) i „obraz” (eikōn). Cień jest czymś o wiele słabszym od obrazu i to zarówno pod względem bytowania jak i ze względu na jego stosunek do rzeczy, której jest odbiciem. Cień w przeciwieństwie do obrazu nie posiada własnego samoistnego bytowania i jest bardzo niedokładnym, niewyraźnym i jednostronnym odbiciem danej rzeczy.

Prawo było tylko cieniem „dóbr przyszłych” a więc dobra te w jakiś tylko bardzo niewyraźny, niedoskonały sposób odbijały się w Starym Przymierzu. Stosunku między Prawem a „dobrami przyszłymi" nie można nawet porównać do tego, jaki zachodzi między obrazem a rzeczywistością, która na tym obrazie jest przedstawiona. Obraz bowiem jest 
o wiele doskonalszym przedstawieniem rzeczywistości niż jej cień.

Egzegeci zgodnie twierdzą, że o ile w ujęciu Listu do Hebrajczyków, Stare Przymierze było cieniem ,dóbr przyszłych”, o tyle Nowe jest ich obrazem. Nowy Testament nie tylko wyobraża „dobra przyszłe”, ale jak stwierdziliśmy poprzednio, już je $w$ pewnym stopniu zawiera, daje w nich uczestnictwo. Twierdzenie to jest zresztą w omawianym obecnie tekście niewyraźnie zawarte. Mieści się bowiem w biblijnym znaczeniu słowa „obraz”, które zawiera w sobie nie tylko ideę przedstawienia innej rzeczywistości, ale także rzeczywiste uczestnictwo w tym, czego jest przedstawieniem. ${ }^{40}$

Stosunek tedy Starego Testamentu do Nowego jest, jak to wynika z omawianego tekstu taki, jaki zachodzi między cieniem a obrazem tej samej rzeczywistości. Nawiasem mówiąc tekst ten stanowi zwięzłą dyspozycję streszczającą rozwój zbawczej ekonomii. Dyspozycję tę można by przedstawić w następujący sposób: cień-obraz (w biblijnym znaczeniu) rzeczywistość. O zakwalifikowaniu danego okresu historii zbawienia do jednego $\mathrm{z}$ tych etapów decyduje stosunek tej epoki do „dóbr przyszłych".

Stwierdziliśmy dotąd, że z perspektywy Starego Testamentu, dzieło Chrystusa stanowi kres rozwoju zbawczego planu. Dlatego też autor posługując się terminologią opartą o Stary Testament, gdzie zachwycające opisy nowej, oczekiwanej ery zajmują wiele miejsca, czy też zaczerpniętą z późniejszej apokaliptyki ${ }^{41}$, która w sposób bardzo kontrastowy przeciwstawiała „czasom pierwszym" „czasy ostateczne” a ,wiekowi obecnemu" „wiek przyszły" usiłuje adresatom, dla których Prawo było mimo wszystko jeszcze teraźniejszością, zwrócić uwagę, że ten oczekiwany ,wiek” już nadszedł. Ekonomia bowiem Syna Bożego, Arcykapłana Jezusa Chrystusa jest okresem dokonania tego wszystkiego, co zapowiadały i przygotowały typy. W zestawieniu zaś tej ekonomii z wiekiem przygotowania, predyspozycji, cieniów i typów jest ona istotnie ,wiekiem przyszłym”, a „dob́ra, którymi wiek ten rozporządza są prawdziwie ,dobrami przyszłymi”.

\section{JAKOSCIOWE ZNACZENIE SEOWA ,PRZYSZEY”}

Opisy nowego eonu, jakich dostarcza nam Stary Testament nie dawały jednak dokładnego jego obrazu. Poszczególne następujące kolejno po sobie fakty, których realizacja miała się dokonywać przez wieki zo-

40 Syn obrazem Boga, por. Kol 1, 15; 2 Kor 4, 4; Hbr 1, 3. Człowiek obrazem Boga, por. Rdz 1, 27; 1 Kor 11, 7. Chrześcijanin obrazem Chrystusa, por. Rz 8, 29; 1 Kor 15, 49; 2 Kor 3, 18; Kol 3, 10.

41 Por. ThW I, $206 \mathrm{n}$. 
staiy przedstawione, jako pojawiające się równocześnie. Stary Testament dostarczał tylko ogólnej i pełnej tajemnic wizji całokształtu czasu. Wizja ta pozwalała jednak na uchwycenie zawartego $w$ nim sensu i dawała świadomość duchowych wymogów, jakie ten czas, stanowiący ramy dla realizacji zbawczego planu stawia przed człowiekiem. Zrealizowana dopiero rzeczywistość dowiodła jak bardzo skrótowa i ogólna była ta wizja.

Wydarzeniem, które wytyczyło granicę przecinającą całą historię zbawienia na dwa okresy i które sankcjonuje w pełni wprowadzenie odnośnie tych dwu okresów terminów „przed” i „po” była, jak stwierdziliśmy, interwencja Boga dokonana za pośrednictwem Chrystusa. Chrystus zapoczątkował czasy eschatologiczne, które od Jego Zmartwychwstania począwszy rozwijają się i zmierzają, jak się okazało, ku swemu ostatecznemu dokonaniu $\mathrm{w}$ sposób, jakiego żaden $\mathrm{z}$ proroków nie był w stanie przewidzieć. Czas osiągnął wprawdzie swoją pełnię, nadszedł „wiek przyszły”, ale ta względna pełnia nie będąc jeszcze ostateczna, nie przyniosła wszystkich zapowiedzianych owoców. Krótko mówiąc rzeczywistość, którą zapoczątkował Chrystus widziana z perspektywy Starego Testamentu w zasadzie jako coś jednego, stałego i ostatecznego. okazała się $\mathrm{w}$ akcie realizacji bardziej złożona, bo obejmująca jeszcze dwa etapy.

Dlatego też chcąc z analizowanej przydawki, określającej tę rzeczywistość, czy też poszczególne jej elementy jako „przyszłe”, wydobyć pełną treść, należy ów zapoczątkowany przez Chrystusa okres rozpatrywać we właściwym mu naturalnym kontekście, czyli mówiąc obrazowo, trzeba umieścić go na osi czasu między poprzednim etapem, a więc Starym Testamentem, w którym tkwi swymi korzeniami, a paruzją, która dopełni i ukoronuje czas Nowego Testamentu tak, jak on sam ukoronował Testament Stary.

Takie dopiero powiązanie może stanowić wystarczające tło dla wydobycia z participium mellōn pełnej treści zamkniętej w słowie tym przez natchnionego autora.

Najpierw stwierdzenie ogólne: wśród licznych, charakterystycznych właściwości jakie Stary Testament przypisywał „czasowi naprawy”, na pierwszy plan wysuwała się idea powrotu przyjaźni między ludzkością a Bogiem. Pierwszym warunkiem powrotu do tego pod pewnym względem pierwotnego stanu było oczywiście odpuszczenie grzechów. Dlatego też autor Listu do Hebrajczyków wielokrotnie i bardzo mocno akcentuje tę właśnie cechę Nowego Przymierza, które jest już faktem

42 Może to być wyrażone w różnej szacie słownej, np. u św. Pawła „niegdyṡ” i „teraz”, por. Ef 2, 12; Kol 1, 22. 
dokonanym. Daje ono oczyszczenie sumienia z uczynków martwych $(9,14)$, obietnicę wiecznego dzidzictwa $(9,15)$ i innych dóbr duchowych potrzebnych do jego osiągnięcia $(7,25 ; 8,10 \mathrm{n}$.). Skoro więc ideał Starego Testamentu wyrażony przez proroka Jeremiasza: ,ja będę im Bogiem, a oni będą mi ludem" został już zrealizowany, zniknęła zatem symbolizowana przez świątynną zasłonę (por. 9, 3; 10, 20) przepaść między światem niebieskim a ludzkością. Wyraźnie prawdę tę wypowiedział autor $w$ omówionym już tekście 12, 22-24. Mówi on nie tyle o usunięciu przeszkód między ludźmi a Bogiem, ile podkreśla pozytywny fakt włączenia i chrześcijan na mocy Nowego Przymierza, w sferę niebieską. Są oni obywatelami miasta Boga żyjącego, niebieskiego Jeruzalem, są w niebie współmieszkańcami aniołów i świętych. Mając przez chrzest $(10,22)$ uczestnictwo w skutkach zbawczego dzieła Chrystusa, stanowią razem z mieszkańcami nieba uroczyste zgromadzenie.

Wnikliwe odczytanie tekstów, w których jest mowa o „dobrach przyszłych" prowadzi nas do wniosku, że rzeczywistości tej nie przedstawił autor tak, jak by była tylko kontynuacją zmienionego i udoskonalonego nieco starego porządku jak sobie to wyobrażała izraelska apokaliptyka, lecz wskazuje na jej, powiedzielibyśmy, rewolucyjną nowość.

Zacznijmy od Arcykapłana tych dóbr. Autor Listu ze szczególną predylekcją mówi o niebieskim pochodzeniu Chrystusa. Czyni to podkreślając bądź jego preegzystencję u Ojca $(1,2 ; 10,5$ n.; 7, 15 n.; 12, 2), bądź też moment powrotu do nieba. Chrystus przebywa w niebie, które jest mieszkaniem Boga. Był u Ojca przed Wcieleniem i tam również, dokonawszy zbawienia, zasiadł po prawicy majestatu na wysokościach $(1,3)$, by wstawiać się za nami przed obliczem Boga. Chrystus rozdaje wiernym „dobra przyszłe" z niebieskiego sanktuarium. Jest bowiem sługą (leitourgōs) „świątyni” i prawdziwego przybytku zbudowanego przez Pana, a nie przez człowieka $(8,2)$. Swoją publiczną funkcję sakralną ${ }^{43}$ spełnia nie na ziemi, lecz $w$ niebie $(8,4)$. Wsezdł tam jako nasz poprzednik (pródromos) i wszedł za nas $(6,20)$. Wstawiennictwo jego polega między innymi na rozdawnictwie ,dóbr przyszłych" $(9,11)$. Tak więc Chrystus jest Arcykapłanem niebieskim, a dobra, które przez ofiarę swoją wysłużył i które rozdaje, są również dobrami niebieskimi.

Przy analizie tekstu 6, 5 stwierdziliśmy, że autor nazywając pewne mesjańskie dobra „mocami przyszłego wieku” nie chciał przede wszystkim podkreślić ich czasowego aspektu, lecz raczej ich nadprzyrodzony charakter. Obecnie widzimy jeszcze jaśniej, że chodzi tu o zaznaczenie niebieskiego pochodzenia i natury tychże darów. W tym świetle bardziej zrozumiały staje się także dalszy kontekst, gdzie jest mowa

43 por. $\mathrm{Rz} 15,16$. 
o konsekwencjach, jakie ściąga na siebie człowiek odrzucający owe niebieskie moce.

Wielokrotnie podkreśliliśmy, że Chrystus Arcykapłan wniósł w obecny świat nową treść, dzięki której znikła nieprzebyta granica oddzielająca ludzkość od Boga. Stwierdziliśmy też, że poddany przez Boga Chrystusowi przyszły świat $(2,57)$, to ten właśnie obecnie istniejący świat, ale pojęty w szczególny sposób. Chodzi mianowicie o świat już odkupiony, czyli ten, który posiada już „moce” i „dobra” niebieskie będące skutkiem arcykapłańskiej ofiary Chrystusa. Wreszcie tekst 10, 1, który został już również omówiony, zawiera przeciwstawienie, czy też raczej konfrontację Prawa i „dóbr przyszłych”. Zestawienie to jest podobne do stosunku, jaki zachodzi między cieniem danej rzeczy, a nią samą. Jeśli równocześnie uświadomimy sobie, że cały regulowany postanowieniami Starego Prawa kult ze wszystkimi jego przejawami nie wyłączając świątyni, nazywa autor obrazem i cieniem rzeczy niebieskich $(8,4$ n.), wówczas łatwiej dostrzeżemy, że przeciwstawienie jest równoważne $\mathrm{z}$ przeciwstawieniem rzeczom ziemskim rzeczy niebieskich.

Przechodząc do podsumowania powyższych wywodów należy stwierdzić, że obok znaczenia czasowego słowo „,przyszły” wskazuje na naturę „przyszłej rzeczywistości”. Słowo to ma zwrócić uwagę czytelników na jej wyjątkową specyfikę, ,przyszły” bowiem oznacza w przytoczonych tekstach tylko co „niebieski”, czyli swoją naturą, pochodzeniem i celem nie należący do struktury tego świata, lecz do rzeczywistości transcedentnej. Jeśli zaś pierwiastek ten jest $w$ świecie obecny i dostępny dla ludzi, to tylko dzięki sprawczej mocy Chrystusowej ofiary.

Biorąc wreszcie pod uwagę konkretny rozwój nowej ekonomii zbawczej w czasie zwłaszcza jej ostateczny kres, który nadejdzie razem z paruzją musimy nadać także temu słowu znaczenie czasowe $\mathrm{w}$ perspektywie tej właśnie przyszłości. Dobra te zatem choć już urzeczywistnione, są jednak mimo wszystko nadal przyszłe w stosunku do teraźniejszości, a to $\mathrm{z}$ tego powodu, że są częściową realizacją rzeczywistości, której pełnia dopiero zaistnieje. Autor natchniony, posługując się znanymi apokaliptyce żydowskiej terminami, nie odrzucił ich czasowego znaczenia, ale równocześnie nadał im nowe zupełnie, bo jakościowe znaczenie.

Wszystko to, co wyżej zostało powiedziane jest następstwem struktury eschatologicznych czasów. Trafnie tę dwufazowość wyraził M. J. Lagrange pisząc, że eschatologia proroków „została przepołowiona”. Teraz też widać jasno, że syganlizowany na początku niniejszej pracy paradoks jest tylko pozorny, a wynika stąd, że w kategoriach czasowych pojawiło się coś, co jest ponad czasem, co należy do wieczności. 
DWUFAZOWA REALIZACJA „ŚWIATA PRZYSZEEGO”

Mając już ustalone precyzyjne znaczenie najważniejszych terminów, możemy ogólnie stwierdzić, że uwzględnione dotąd teksty przedstawiają nam eon eschatologiczny w podwójnej fazie. Dlatego też możemy je podzielić na dwie grupy.

Jedne z nich mówią o rzeczywistości niebieskiej, która jako właściwa przede wszystkim Bogu, a następnie innym także niebianom, dla chrześcijan pozostaje, jako coś przyszłego, w sferze obietnicy. Są to dla chrześcijan rzeczy należące do pełnego nadziei porządku oczekiwania. Gwarancją zaś i fundamentem owego czekania jest wiara. Rzeczywistość ta jest ostatecznym kresem i sensem chrześcijańskiego dążenia i wszystkich wysiłków. Treść ta zawiera się w obrazowej szacie słownej: „,przyszłego” lub „,stałego miasta” $(13,14)$, „przybytku”, do którego wszedł Chrystus $(9,12)$, „odpoczynku Bożego” (4, 1 n.). Dla określenia tego samego używa też autor po prostu słowa „niebo" (9, 24). Przedstawiony $\mathrm{w}$ ten sposób świat niebieski jest jednak według tych tekstów dla chrześcijan dostępny i możliwy do osiągnięcia. Chociaż jego posiadanie jest jeszcze dla ludzi pielgrzymujących dość odległe, to jest jednak realne i podejmowanie wysiłków, by stało się faktem jest dla chrześcijan czymś najbardziej podstawowym. Do tego stopnia, że autor sțwierdza po prostu fakt: „,Szukamy tego [miasta], które ma przyjść” $(13,14)$. Rzeczywistość tę zwykle określa się jako „eon eschatologiczny w znaczeniu ścisłym".

Druga natomiast grupa tekstów mówi o eonie eschatologicznym w sensie szerszym o świecie przyszłym, ale już urzeczywistnionym, a więc takim, który nie tylko jest przedmiotem nadziei, - $\mathrm{w}$ tym znaczeniu, że dopiero kiedyś zaistnieje, ale już faktycznie jest zrealizowany w doczesności i dostępny dla ludzi szukających „miasta przyszłego”.

Jasną jest rzeczą, że między tymi dwoma sposobami przedstawienia rzeczywistości niebieskiej nie ma cienia sprzeczności.

Czytając teksty grupy pierwszej, a więc te w których ,świat przyszły" spełnia rolę raczej bodźca psychologicznego ponaglającego wiernych do wysiłków, łatwo dochodzimy do wniosku, że chodzi tu o jakąś pełnię, o coś, co jest już w stanie ostatecznego dokonania. Autor pokazuje rzeczywistość tę jako należną Bogu i Chrystusowi, a obrazem, który ilustruje sposób korzystania z niej przez ludzi jest zamieszkanie. Dobra zaś przyszłe, których zakosztowali już chrześcijanie mają, jak wynika z tekstu, charakter cząstkowy. $\mathrm{Na}$ ich zaczątkowość wskazują chociażby takie czasowniki, jak ,zakosztowali" lub „przystąpili”. Przed dobrami tymi stoi stopniowy rozwój aż do przejścia w pełnię. Między pełną rzeczywistością niebieską, a tą jej częścią, która jest urzeczywistniona 
w doczesności zachodzi tylko różnica stopnia, a nie jakości. Krótko mówiąc jest to ta sama rzeczywistość, lecz na różnym stopniu realizacji.

\section{FFOBLEM PRZEJŚCIA ZREALIZOWANYCH JUŻ „DÓBR PRZYSZEYCH” W PEENIE}

$\mathrm{Z}$ tego, co zostało już powiedziane, można by wysnuć wniosek, że przejście obecnego eonu eschatologicznego $\mathrm{w}$ jego pełnię dokonuje się na płaszczyźnie indywidualnego życia i dokona się w całości w dniu paruzji na drodze rozwoju, bez jakichś wstrząsów dotykających jego istoty. Stwierdziliśmy bowiem, że jest to ta sama rzeczywistość. Myśl ta znajduje również, przynajmniej częściowe potwierdzenie w następującym tekście: „Głos Jego wstrząsnął wówczas ziemią, a teraz obiecuje mówiąc: Jeszcze raz wstrząsnę nie tylko ziemią ale i niebem. Te zaś słowa jeszcze raz wskazują, że nastąpi zniszczenie (przemiana?) tego, co zniszczalne, a więc co zostało stworzone, aby pozostało to, co jest niewzruszone. Dlatego też niewzruszone otrzymując królestwo, miejmy laskę, a przez nią służmy Bogu ze czcią i bojaźnią." (12, 26 n.).

Naprzód trzeba zrobić zastrzeżenie, że wstrząsy, o których mowa w powyższym zdaniu nie odnoszą się bynajmniej do „końca świata” $\mathrm{w}$ dniu paruzji. Nie ma tu autor na myśli zniszczenia materii w dniu ostatecznym. Jest natomiast mowa o dwu Przymierzach. Kilka wierszy wcześniej przeciwstawiał autor, jak pamiętamy Przymierze Nowe Staremu. Obecny tekst jest kontynuacją tych rozważań. Poruszanym więc zagadnieniem jest sprawa porozumienia zawartego między Bogiem a człowiekiem. Chodzi o porozumienie zawarte $w$ dwu etapach, stanowiących fundament dla kształtującego się odniesienia wzajemnego między Bogiem a człowiekiem. Stąd też zawarte w przytoczonych wierszach przeciwstawienie „rzeczom niezniszczalnym” „rzeczy zniszczalnych”, lub inaczej ,,stworzonych" nie odnosi się do ogółu bytów. Przeciwstawiania tego nie można rozumieć jako świat materii z jednej, a świat transcendentny $\mathrm{z}$ drugiej strony. Chodzi tu bowiem o przeciwstawienie w ściśle ograniczonym zakresie. Jest mianowicie mowa o tym, co było materialne, zniszczalne w Starym Przymierzu i co zgodnie ze swą naturą zostało wstrząśnięte (por. też 8,13), zdezaktualizowane i jest mowa o tym, co jest trwałego w Nowym Przymierzu i co pozostanie. Tym, co niewzruszone, jest właśnie Królestwo, które otrzymują chrześcijanie, a więc Królestwo Boże, w którym obywatele posiadają „dobra przyszłe”, czyli łaskę i przystęp do Boga. Autor pisząc o wstrząsach ma na myśli ogłoszenie obu Przymierzy. Pierwszy wstrząs towarzyszył ogłoszeniu Przymierza na Synaju, drugi zaś ogłoszeniu Przymierza Nowego, którego typem jest góra Syjon. 
Dla lepszego zrozumienia tekstu konieczne jest jeszcze wyjaśnienie, że o drugim wstrząsie autor pisze już po fakcie, po jego dokonaniu, ale pisze $\mathrm{z}$ pozycji jeszcze niedokonanej, tak, jakby to jeszcze nie nastąpiło. Pisze on te słowa $\mathrm{z}$ perspektywy Starego Testamentu. Posługuje się proroctwem przytaczając je w brzmieniu dosłownym, stąd pochodzi czas przyszły: „jeszcze raz wstrząsnę”. Adresaci doskonale rozumieli myśl autora, że faktycznie proroctwo zostało spełnione i oba wstrząsy miały już miejsce. Występujące $\mathrm{w}$ tekście dwa pozornie odnoszące się do różnych okresów historii zbawienia okoliczniki „wówczas” (tóte) i „teraz” (nyn) chociaż odnoszą się do różnej treści zawartej w poszczególnych częściach tego zdania, to jednak odnoszą się wyłącznie do Starego Testamentu. Tóte łączy się z esáleusen, co oznacza „wstrząsnął wówczas". Wyrażenie to stanowi aluzję do znanego adresatom faktu, że zawarciu przymierza towarzyszyły materialne wstrząsy, zaburzenia $\mathrm{w}$ przyrodzie. Nyn natomiast wiąże się $\mathrm{z}$ występującym w perfectum czasownikiem epéggeltai i oznacza, że trwa nadal dana przez Boga obietnica: „,jeszcze raz wstrząsnę nie tylko ziemią, ale i niebem." Są to słowa wzięte żywcem od proroka Aggeusza ${ }^{44}$ i odnoszą się do czasów mesjańskich. Jest to po prostu wizja zjawisk towarzyszących ogłoszeniu Nowego Przymierza.45 Autor cytując proroka nie zmienia sensu jego wypowiedzi. Znamy wprawdzie wypadki, że cytowanym fragmentom ze Starego Testamentu autorowie ksiąg Nowego Testamentu nadają nowe, nieznane dotąd znaczenie, ale wówczas wynika to jasno z kontekstu. Tu zaś na taki zabieg nic nie wskazuje.

Nie ma więc $w$ przytoczonych słowach mowy o końcu świata, chyba w tym znaczeniu, że era mesjańska jest już ostatnią epoką, która stale rozwija się i zmierza do tego właśnie końca. Uściślając, trzeba powiedzieć, że słowa te wprost i bezpośrednio nie odnoszą się do dnia ostatecznego, a tym bardziej nie zajmują się losami materialnego świata po powtórnym przyjściu Chrystusa. Mówią natomiast o dwóch przymierzach: Starym, którego ogłoszenie wstrząsnęło górą Synaj i Nowym, którego promulgacja dokonała się na Golgocie w chwili skonania Chrystusa wśród powszechnego zamieszania $\mathrm{w}$ przyrodzie ${ }^{46} \mathrm{i}$ w chwili zmartwychwstania. Stare Przymierze, większość jego praw, instytucje i obrzędy miały charakter przygotowawczy, a więc $\mathrm{z}$ istoty swej skazane było na usunięcie i ustąpienie miejsca innemu. Dlatego też wszystko, co było właśnie takim, co spełniło już swoje zadanie, zostało z chwilą ogłoszenia Nowego Przymierza usunięte. Tymczasowa i zniszczalna rze-

44 Ag 2, 6.

$45 \mathrm{~W}$ ten sposób rozumieli tego rodzaju przepowiednie sami Apostołowie. Kon. kretnie np. św. Piotr mówi, że w dniu Zesłania Ducha Swiętego zrealizowała się przepowiednia proroka Joela, por. Dz 2, $15 \mathrm{n}$. 
czywistość została usunięta w tym celu, by pozostało to, co jest stałe, niewzruszalne, nieusuwalne. Nowe Przymierze, które zajęło miejsce Starego jest zatem ostateczną rzeczywistością, która trwać będzie bez przerwy i bez takiego wstrząsu, który by wprowadził w nią jakąś destrukcję, jakąśs przemianę dotykającą istoty tej rzeczywistości. Możliwa jest tylko zmiana $\mathrm{w}$ kierunku stałego wzrostu ilości aż do pełnego jej posiadania po przekroczeniu granicy czasu.

Fakt, że nie chodzi w omawianym zdaniu o koniec świata, lecz o zapoczątkowanie ery mesjańskiej, potwierdza też następny wiersz: „Dlatego też niewzruszone otrzymując królestwo, miejmy łaskę, a przez nią służmy Bogu ze czcią i bojaźnią."

Wprowadzony tu spójnik przyczynowy „dlatego" sprawia, że te dwa zdania, to znaczy poprzednio omówione i obecne, ściśle się ze sobą łączą i mówią o tej samej rzeczy. Możemy więc na tej podstawie powiedzieć, że „to, co jest niewzruszone" i ,niewzruszone” królestwo w tym kontekście oznaczają tę samą rzeczywistość. Nowy więc nie podlegający już żadnym istotnym wstrząsom porządek rzeczy utożsamia autor z Królestwem Bożym, $\mathrm{z}$ niezmiennym i wiecznym Królestwem Chrystusa. ${ }^{47}$ Królestwo to otrzymują chrześcijanie. Zastosowany tu czas praesens świadczy o ciągłym otrzymywaniu i posiadaniu już obecnie niewzruszonego Królestwa Bożego. Samo przejście z obecnie zrealizowanej części do pełni, dokona się zatem bez wstrząsów, bez zmiany tego, co już posiadamy, a więc dokona się na sposób dopełnienia.

\section{ZAKOÑCZENIE}

Przedstawiona wyżej eschatologiczna koncepcja Listu do Hebrajczyków bardzo rozszerza nasze horyzonty w spojrzeniu na zagadnienie czasu i wieczności, na problem stosunku rzeczywistości niebieskiej do doczesności. Krótko mówiąc takie spojrzenie, jakiego dostarcza nam wspomniany List, ukazuje w pełnym świetle specyfikę czasów Nowego Testamentu.

Nade wszystko ważne jest uświadomienie sobie, że rzeczywistość eschatologiczna $\mathrm{z}$ istoty swej należąca ciągle do przyszłości jest równocześnie faktem aktualnym, który stale się dokonuje i rozwija od Zmartwychwstania Chrystusowego począwszy, aż do jego powtórnego przyjścia. Fakt ten stanowi do tego stopnia istotny współczynnik „,czasu

46 Por. Mt 24, 29; 27, 51 n.; 王 23, 47 n. Zresztą niekoniecznie musiało tu chodzić o wstrząsy materialne. Ogłoszenie Nowego Przymierza i zestawienie go ze Starym było przecież potężnym wstrząsem dla starej ekonomii i tych, którzy w niej żyli, por. np. Gal 3, 23 n.; 5, 15.

47 Por. Ek 1, 32 n.; 1 Kor 15, 25 n.; 2 P 1, 11; Ap 11, 15. 
Kościoła", że bez niego nie może być zrozumiany ani Kościół, ani co więcej nie może być zrozumiana sama Ewangelia.

Takiemu też ujęciu eschatologii dał wyraz Sobór Watykański II, zwłaszcza w rozdziale Konstytucji Dogmatycznej o Kościele zatytułowanym „Eschatologiczny charakter Kościoła pielgrzymującego i jego związek z Kościołem w niebie".

\section{Z U S A M M E N A S S U N G}

\section{DIE ESCHATOLOGISCHE WIRKLICHKEIT IM BRIEFE AN DIE HEBRÄER}

Auf Grund des Briefes an die Hebräer erörtert der Verfasser des Artikels das Problem des eschatologischen Eons im weiteren Sinn des Wortes. Das Wesen des Problems liegt darin, dass der Autor des erwähnten Briefes die Dinge, die der Struktur der ,zukünftigen Welt" gehören, als schon gegenwärtige, in der Welt vorkommende darstellt. Einen Widerspruch scheinen auf den ersten Bliick die Behauptungen zu enthalten, dass Christen die „Kraft der zukünftigen Weltzeit" $(6,5)$ schon gekostet haben, dass Christus als „Hohepriester der zukünftigen Güter" $(9,11)$ auf der Erde erschienen ist und dass es Ihm selbst und nicht den Engeln Gott die ,zukünftige Welt” unterordnet hat. Die zukünftige Wirklichkeit ist nämlich hier als schon realisiert dargestellt. Die Analyse dieser Texte, in denen das Wort mellōn auftritt, sowie anderer, die auf dieses Problem ein Licht werfen, z. B. 12, 18f., erlaubt die Bedeutung des Wortes ,zukünftig” festzulegen und den theologischen Inhalt darus zu entnehmen.

Die „Kräfte der zukünftigen Weltzeit” werden in der Reihe folgender Gaben genannt: Erleuchtung, Kosten der himmlischen Gabe, Teilnahme an Heiligen Geist, Freude am herrlichen Wort Gottes. Die geistige Erleuchtung, von der hier die Rede ist, hatte die Tradition so sehr mit dem Moment des Empfangs der Taufe verbunden, dass dieses Sakrament selbst phötismós genannt wurde. Die himmlische Gabe, welche die Christen gekostet haben, die geistige Nahrung also, bedeutet hier weder die Eucharistie noch einen solchen Akt, der erneut werden kann, weil man hier von etwas Einmaligen (hápaks) spricht. Die Teilnahme am Heiligen Geist kann sich sowohl auf die Taufe, wie auch auf die Zeremonie der Handauflegung beziehen, sie kann aber auch die Charismata bedeuten. Ein gutes Wort Gottes ist natürlich die Gute Nachricht, die die Verwirklichung der Verheissungen Gottes ankündigt und die Richtung des menschlichen Tuns festsetzt.

Schliesslich ist die Rede davon, dass die Christen die „Kraft der künftigen Weltzeit" gekostet, d.h. persönlich erfahren haben. Das hier angewandte Partizip Aorist weist auf die vollendete Tatsache hin, dabei stehen aber die Christen vor der Gefahr, diese Gaben zu verlieren; es handelt sich also um eine schon im Diesseits vorhandene Wirklichkeit. Dies alles erlaubt den Schluss zu ziehen, dass die erwähnten Gaben die Gnaden umfassen, die eine Folge der Taufe sind und diejenigen, zu denen die Taufe den Weg eröfłnet. Man kann also kurz sagen, dass in diesen Begriffen vor allem eine Wirklichkeit verborgen ist, welche die Theologie als sakramentale Gaben bezeichnet. Der Ausdruck „Kräfte” (dýnamis) weist 
auf den aktiven, dynamischen Charakter der Gabe, die ,zukünftig” genannt wird, hin.

Von grosser Bedeutung ist für unser Thema auch der Text 12, 18f., der in anderen Worten von derselben Wirklichkeit spricht, und zwar von der Tatsache einer reellen Teilnahme der Christen an der himlischen Wirklichkeit. In Übereinstimmung mit diesem Text wurden nämlich die auf der Erde lebenden Christen kraft des Neuen Bundes in die himmlische Sphäre eingeschlossen. Sie sind schon die Bürger der Stadt des lebenden Gottes, des himmlischen Jerusalems; sile sind im Himmel die Mitbewohner der Engel und der Heiligen und zusammen mit den Himmelsbewohnern bilden se ene Festversammlung (panēgyris).

Der Urheber dieses Sachverhalts ist Christus, der erschienen ist (Aorist), was bedeutet, dass Er im historischen Moment in den Lauf der Zeit als „Hoherpriester der zukünftigen Güter" eingetreten ist. Diese Güter, die eine Frucht seiner Tätigkeit als Erzpriester sind, hat der Vater Ihm als einem Mittler des Neuen Bundes unterworfen.

Sehr charakteristisch ist die Tatsache, dass der Verfasser des Briefes an ${ }^{-}$die Hebräer von den verwirklichten zukünftigen Gütern fast immer im Kontexst des Bundes spricht. Die Úberlegenheit des Neuen Bundes über dem Alten zu beweisen, ist das Haptziel dieses Briefes. Die Ankündigung der Botschaft von den „zukünftigen Gütern”, die schon realisiert wurden und das wesentliche Element der neuen Zeit bilden, scheint also trotz der geringen Zahl der Texte eines der Hauptelemente dieses Briefes zu sein.

In den Schlussfolgerungen stellt der Verfasser des Artikels fest, dass dem Attribut mellōn neben der relativen, zeitlichen Bedeutung noch eine qualitative beizumessen ist. So besitzt also das Wort ,zukünftig” in den besprochenen Texten vorest eine ursprüngliche und vom Standpunkt der Semantik eingentümliche Bedeutung. Es bezeichnet die Wirklichkeiten, auf die es sich bezieht, als die zukünftigen, d.h. die späteren im Verhältnis zu der vorhergehenden Zeit, wo sie noch der Gegenstand der Verheissung und der Erwartung waren. Dies ergibt sich aus der konkreten Verwirklichung des Gottesheilsplans, dessen wichtigste Etapen man auf Grund des Briefes an die Hebräer in folgendes Schema fassen kann: Schatten - Bild (im biblischen Sinn) - Wirklichkeit. Die besprochenen Texte machen also die Leser, für die das Gesetz trotz allem noch eine Gegenwart war, darauf aufmerksam, dass die erwartete Weltzeit schon angekommen ist. Gleichzeitig weist das Attribut ,zukünftig" auf den inneren Inhalt der neuen Wirklichkeit hin. Erst ihr Vorhandensein hat bewiesen, wie allgemein und verkürzt die Vision des Alten Testaments war. Die Zeit hat ihre Fülle erreicht, "die zukünftige Weltzeit" ist: gekommen, diese relative Fülle hat aber nicht alle erhofften Früchte gebracht, da sie noch nicht endgültig war. Man muss also die von Christus begonnene Weltzeit. in einem ihr eigenen natürlichen Kontext betrachten, d.h. man soll sie, um bildlich zu sagen, auf der Zeitachse zwischen der vorhergehenden Etape placieren, also zwischen dem Alten Testament, in dem es tief eingewurzelt ist und der $\mathrm{Pa}-$ rusie, welche die Zeit des Neuen Testaments ergänzen und krönen wird, wie jene das Alte Testament gekrönt hatte. Indem wir die besprochenen Texte auf diesem Grund ablesen, können wir feststellen, dass „zukünftig” soviel wie „himlisch” also in die Ewigkeit, in die Welt Gottes übergehend bedeutet, was heisst, dass es mit seiner Natur, seiner Herkunft und seinem Ziel nicht der Struktur dieser Welt, sondern der transzendenten Wirklichkeit gehört. Diese Güter haben einen anfänglichen Charakter und auf ihre Anfänglichkeit weist unter anderem der Gebrauch solcher Zeitwörter hin, wie ,kosten” oder „herantreten”. 
Eine andere Gruppe der Texte spricht vom eschatologischen Eon im exakten Sinn, also von der Fülle der himmlischen Wirklichkeit, die, weil sie vor allem Gott und Christus, dann aber auch anderen Himmelswesen eigen ist, für Christen als etwas Zukünftiges in der Sphäre der Verheissung bleibt und zur hoffnungsvollen Ordnung der Erwartung gehört. Die Garantie und das Fundament jener Erwartung bildet der Glaube. Diese Wirklichkeit ist die endgültige Grenze des christlichen Strebens und aller Bemühungen. Dieser Inhalt ist in solchen Begriffen enthalten wie ,zukünftig” oder ,bleibende Stadt” (vgl. 13, 14), das Heiligste, in das Christus eingetreten ist (vgl. 9, 12), „Ruhe Gottes” (vgl. 4, 1 f.). Um dasselbe zu bezeichnen gebraucht der Verfasser des Briefes auch ganz einfach das Wort „Himmel” (vgl. 9, 24). Zwischen der Fülle der himmlischen Wirklichkeit, die der Gegenstand des Strebens ist, und ihrem Teil, der bereits im Diesseits verwirklicht ist, besteht nur ein Unterschied des Grades, nicht aber der Qualität. Kurz gesagt ist das dieselbe Wirklichkeit, die sich nur auf verschiedener Realisationsstufe befindet. Vor den schon verwirklichten ,zukünftigen Gütern” steht eine Stufenentwicklung bis zum Übergang in die Fülle. Dieser Übergang wird sich schon ohne diejenigen Erschütterungen vollziehen, die das Wesen der ,zukünftigen Güter" bedrohen würden.

Dank der eschatologischen Konzeption des Briefes an die Hebräer erweitern sich unsere Horizonte im Hinblick auf das Problem der Zeit und der Ewigkeit, auf das Problem des Verhältnisses der himmlischen Wirklichkeit zum Diesseits. Der Brief zeigt, dass man die gegenseitige Abhängigkeit zwischen dem gegenwärtigen und künftigen Leben keineswegs auf das moralische Gebiet beschränken darf, weil in diesen aktuelle Beziehungen ontologischer Natur vorkommen. Ein solcher, durch den Brief an die Hebräer gelieferter Einblick zeigt uns in vollem Licht die Spezifität der Zeit des Neuen Testaments. Vor allem ist es wichtig, sich dessen bewusst zu sein, dass die eschatologische Wirklichkeit, die ibrem Wesen nach immer der Zukunft angehört, gleichzeitig eine aktuelle, ständig werdende und seit der Auferstehung bis zur wiederholten Ankunft Christi sich entwickelnde Tatsache ist. Diese Tatsache bildet den wesentlichen Koeffizienten der ,Zeit der Kirche" in dem Grade, dass ohne ihn weder die Kirche verstanden wird, noch, was wichtiger ist, das Evangelium selbst zu verstehen wäre. 